\section{A Further Note on the 'Unmasking' of Lipids in the Cell}

Since the author' reported on the 'Unmasking' effect of $1 \%$ phenol on the lipids in the oocytes of Chrotogomus, some more observations ${ }^{2,3}$ have become available on the subject which prompt a further comment on the phenomenon of 'masking' in lipids.

BERENBAUM ${ }^{2}$ has reported on the use of sudan black $B$ in his 'Acetone-Sudan black', 'Burnt Sudan black', and 'Ethanolic Sudan black at $60^{\circ} \mathrm{C}$ ' techniques for colouring the firmly bound lipids of the cell nuclei, reticulin and epithelial brush borders, etc. CLAYTON ${ }^{3}$ has investigated the 'unmasking' influence of a number of lipid solvents on the acroblast in $A$ cheta domesticus, and has found $90 \%$ ethanol and $5 \%$ hydroquinone to be the most effective 'unmasking' agents.

Both these papers deal with the techniques which 'unmask' lipids bound firmly with proteins to form lipoproteins. The influence of lipid solvents in breaking the bonds between lipoproteins, and consequently releasing the lipids, has been widely recognized by the biochemists ${ }^{4}$. In this laboratory also, the 'unmasking' effect of acetone and ethanol, especially on the lipoproteins of the mitochondria in oocytes, has very often been observed ${ }^{5-7}$.

NATH, Gupta et al. ${ }^{5-7}$ have observed in the oocytes of a number of insects three kinds of lipid bodies viz. (1) $L_{1}$ bodies having a phospholipid or lipoprotein nature, (2) $L_{2}$ bodies having a phospholipid sheath surrounding a triglyceride core, and (3) $L_{3}$ bodies of a pure triglyceride nature.

The $L_{2}$ bodies show a duplex appearance with a completely sudanophobe core and a sudanophil cortex, in all the variants of sudan black $B^{8-10}$, even at $60^{\circ} \mathrm{C}$. After a treatment in $1 \%$ phenol, either of the material or the gelatine sections, these $L_{2}$ bodies colour homogeneously in sudan black. Their duplex appearance is again restored after a simple treatment of the 'unmasked' sections in cold acetone for $12-24 \mathrm{~h}$. The cores colour pink in nile blue ${ }^{11}$ while the sheaths are blue. Further, the cores of the $L_{\mathrm{z}}$ bodies are negative to acid hematein ${ }^{12}$, Schultz's variants ${ }^{13}$, mercuric-bromophenol blue ${ }^{14}$ (for proteins), and PAS ${ }^{15}$ (for carbohydrates). All these tests establish the presence of triglycerides in them.

Now, the triglycerides are not known to form lipoprotein complexes ${ }^{16,17}$. It is implicit, therefore, that some other phenomenon is involved which keeps the triglycerides

1 B. L. Gupta, Nature 181, 555 (1958).

2 M. S. Berenbaum, Quart. J. micr. Sci. 99, 231 (1958).

3 BeANcre-P. Clayton, Quart. J. micr. Sel. 99 , in press.

4 J. A. Lovern, Chemistry of Lipids of Biochenical Significance (Methuens Ltd., London 1955).

5 V. Nath, B. L. Gupta, and B. LAL, Quart. J. micr. Sci. 99, 315 (1958).

6 V. Nath, B. L. Gupta, and D. K. Agarwal, La Cellule, in press.

7 V.NAth, B, L. Gupta et al., unpublished observations.

J. R. Baker, Quart. J. micr. Sci. 90, 293 (1949).

- R. D. Lullie, Histopathologic Technic (Blakinston Inc., N. Y. 1954).

10 T. L. Chrmple and F. A. Purt, Stain Techn, 26, 51 (1951).

11 A. J. CAIN, Quart. J. micr. Sci. 88, 383 (1947); 89, 429 (1948).

12 J. R. BAKer, Quart. J. micr. Sci. 87, 441 (19.16).

13 G. Gomori, Microscopic Histochemistry (University Press, Chicago 1955).

14 D. MAziA, P. Brewer, and M. Alfert, Biol, Bull, 104, 57 (1953).

15 A. G. E. PEARse, Histochemistyy (Churchill Ltd., London 1954).

16 A. J. Cain, Biol. Rev. 25, 73 (1950).

17 F. Charcaff, Adv. Prot. Chem. 1, (1944). in a 'masked' condition in such mixed lipid bodies, widely occurring in oocytes?.

SснмiDT ${ }^{18}$ had suggested that the phospholipid spheres probably have a series of concentric shells of water in between the bimolecular layers of the phospholipid molecules. He has also drawn a 'water vacuole' surrounded by a bimolecular layer of phospholipids ${ }^{19}$. This observation has been fully confirmed recently by Ross and CHou ${ }^{19}$. $\mathrm{HIRSCH}^{20}$ and $\mathrm{NATH}^{21}$ have often pointed out that such 'osmiophobic' parts of duplex vesicles act as the sites where cell secretions, including fat (triglycerides), are condensed. To the author, it appears that in the $L_{2}$ bodies mentioned above the triglyceride cores and the phospholipid sheaths remain separated by a thin layer of water molecules which form an impermeable membrane for the water-insoluble physical lipid colorants like sudan black $B$ or sudan III and IV, etc. The ethanol or acetone of sudan solutions should be able to break the water barriers, but they dissolve away the triglycerides also in prolonged treatments and therefore are unable to reveal their 'unmasking' influence. Phenol, on the other hand, might attack the water molecules without destroying any lipids. It is interesting to note that in $\mathrm{OsO}_{4}$ preparations like Lewitsky-saline 22 (unstained), these $L_{2}$ bodies always appear as homogeneously black spheres: but if such sections are bleached in $\mathrm{H}_{2} \mathrm{O}_{2}$ and then coloured with sudan black ${ }^{22}$, the $L_{2}$ bodies again appear as rings ${ }^{7,23}$.

It is clear, therefore, that in such cases as the $L_{2}$ bodies in oocytes, the 'masking' is a purely physical phenomenon involving technical difficulties in colouring. This would add another possibility to CIACcro's ${ }^{24}$ undefined ${ }^{16}$ term of 'masked' lipids.

Brij L. Gupta

Department of Zoology, Panjab University, Hoshiarpur (India), December 18, 1958.

\section{Résıtmé}

Les triglycérides se trouvant à l'intérieur de quelques corps lipides, dans les oocytes paraissent masqués lorsqu'on utilise des colorants pour lipides. C'est peut-être à cause de la présence d'une couche de molécules d'eau entre les molécules phospholipides de la gaine et les molécules des triglycérides du cour. Cet écran interposé par l'eau est détruit d'une manière ou d'une autre par une solution d'1\% de phénol et ainsi le umasque» disparait.

18 W. T. Scimidr, Nova Acta Leopoldina 7,1 (1939).

$19 \mathrm{~K}$. F. A. Ross and J. T. Y. Chov, Quart. J. micr. Sci. 98,341 (1957).

${ }^{20}$ G. C. Hrrsch, Symposium on Cell Secretion (Belo Horisonte, Brazil 1955

21 V. NAth, Res. Bull. Panjab Univ. $95-99,1$ (1957)

22 J. R. BAKLr, Quart. J. micr. Sci. 97, 621 (1956).

23 J. R. BAker, Principals of Biological Mticro-technique (Methnens Ltd., London 1958).

${ }^{24}$ G. Craccio, Boll. Soc. ital. Biol. sper. 1, 47 (1926).

\section{Intraspecific Sexual Preferences in Drosophila prosaltans Duda and in Drosophila equinoxialis Dobzhansky}

By direct observation ${ }^{\mathbf{1 , 2}}$ of courtship and mating behaviour of neotropical strains of Drosophila prosaltans Duda

1 H. T. SPTETh, Evolution 3, 67 (1949).

2 A. H. Sturtevant, Carnegie Inst. Wash. 301, 1 (1921). 